\title{
Eurozone Crisis Scenario: Possible Developments and Lessons for Economic Integration Communities with Participation of Russia
}

\author{
D. Bracchi' ${ }^{1}$, V.V. Maslennikov' ${ }^{2}$ A.S. Linnikov ${ }^{3}$ \\ ${ }^{1}$ Order of Advocates of the City of Milan, Italy \\ http://orcid.org/0000-0002-7779-9645 \\ ${ }^{2}$ Financial University, Moscow, Russia \\ http://orcid.org/0000-0001-6199-9979 \\ ${ }^{3}$ Advocate of the Moscow Regional \\ Chamber of Advocates, Moscow, Russia \\ http://orcid.org/0000-0002-4913-2966
}

\begin{abstract}
Topic. The article reviews the legal possibility of full or partial EMU breakup (EURO-crack). The authors conducted jurisprudential researches of the European experience and compare both the provisions of the EU and Eurasian Economic Union (EAEU) documents (Treaty, Protocol 15) and integration processes maturity of the latter.

Purpose. The purpose of the article is to consider possible mechanisms and consequences of European Union (EU) member states exit from the economic and monetary union (EMU); to assess the applicability of the European experience to the development of monetary and economic integration among member states of Eurasian Economic Union (EAEU).

Methodology. The authors of the article use scenario analysis method to assess legal grounds, procedures, mechanisms and consequences of EU member states exit from the economic and monetary union for the ongoing one (Brexit) and the most probable options.

Results. The authors systematize and conduct consistent analysis of prerequisites, the chronology of formation of various European integration associations, fundamental legal documents and key milestones in the formation of monetary integration in the EU, the stages of European EMU development in its contemporary form. They include an exit from Eurozone: with further immediate application for repeat accession without taking part in the monetary union; retaining the EU membership based on the provisions of Vienna Convention regarding the law of treaties and that arising out of the Treaty on the functioning of the EU.

Conclusions. The authors conclude that the modern system of international law provides an effective denouncement mechanism of the Treaty on European Union and its individual provisions. They argue the possibility of changing the legal status of member States with varying degrees of participation in EMU and, on the example of Italy, criticized the initiative for a unilateral exit of a member state of the EMU.

Jurisprudential researches of the European experience conducted by the authors, allowed them to compare the provisions of the documents of the EU and the Eurasian Economic Union (EAEU) (Treaty, Protocol 15)), and the degree of maturity of the integration processes of the latter. Conclusions made by the authors about the prospects of economic and monetary integration of member States of the EAEU are the base of recommendations for action concerning deepening economic integration and creation of common financial market of the EEU. Conclusions made by the authors are also relevant to state authorities of the Russian Federation, including economic authorities and organs of diplomacy.

Keywords: European Union; Eurasian Economic Union; economic and monetary union; economic integration; legal status; European experience; exit from EMU.

Citation: Bracchi D., Maslennikov V.V., Linnikov A.S. Eurozone Crisis Scenario: Possible Developments and Lessons for Economic Integration Communities with Participation of Russia. Finansy: teoriya i praktika = Finance: Theory and Practice, 2017, vol. 21, no. 5, pp. 72-81. (In Russ.). УДК 339.9

JEL F36

DOI 10.26794/2587-5671-2017-21-5-72-81
\end{abstract}




\title{
Кризисный сценарий для «Еврозоны»: варианты развития событий и уроки для экономических интеграционных объединений с участием России
}

\author{
Д. Бракки ${ }^{1}$, В.В. Масленников ${ }^{2}$, А.С. Линников ${ }^{3}$ \\ ${ }^{1}$ Орден адвокатов города Милана (Италия), \\ http://orcid.org/0000-0002-7779-9645 \\ ${ }^{2}$ Финансовый университет, Москва, Россия \\ http://orcid.org/0000-0001-6199-9979 \\ ${ }^{3}$ Адвокатская Палата Московской области, Москва, Россия \\ http://orcid.org/0000-0002-4913-2966
}

\begin{abstract}
АННОТАЦИЯ
Предмет. В статье исследуются правовые возможности полного или частичного выхода из Экономического и валютного союза (ЭВС) стран ЕС. С этой целью авторы провели правоведческие исследования опыта европейских страх и сравнили положения основных документов ЕС и Евразийского экономического союза (ЕАЭС) (Трактат, Протокол № 15), а также зрелость интеграционных процессов в ЕАЭС.

Цель. Рассмотрение возможных механизмов и последствий выхода государств-членов Европейского союза (ЕС) из экономического и валютного союза (ЭВС), оценка применимости европейского опыта для развития валютно-экономической интеграции стран Евразийского экономического союза (ЕАЭС).

Методология. Авторы статьи используют метод сценарного анализа для оценки правовых оснований, процедур, механизмов и последствий выхода государств-членов ЕС из экономического и валютного союза для уже реализуемого (Brexit) и наиболее вероятных вариантов.

Результаты: Для этого авторы систематизируют и последовательно анализируют предпосылки, хронологию формирования различных интеграционных объединений Европы, основополагающие юридические документы и ключевые вехи становления валютной интеграции в ЕС, этапы формирования в Европе ЭВС в его современном виде. В статье рассматривается вероятность полного или частичного распада ЭBC (EURO-crack). B их числе выход из Еврозоны: с последующим немедленным направлением заявки на повторное вступление, без участия в валютном союзе; с сохранением членства в ЕС по основаниям, предусмотренным Венской конвенции о праве международных договоров или вытекающим из Договора о функционировании ЕС.

Выводы. Авторы делают выводы о том, что современная система международного права содержит эффективный механизм денонсации Договора о ЕС и отдельных его положений. Аргументируют они и возможность изменения правового статуса государств-членов с разной степенью участия в ЭВС и, на примере Италии, приводят критику инициативы по одностороннему выходу государства-члена из ЭВС.

Правовое исследование европейского опыта, проведенное авторами, позволило им сопоставить и положения документов ЕС и Евразийского экономического союза (ЕАЭС) (Договора, Протокола 15), и степень зрелости интеграционных процессов последнего. Сделанные авторами выводы о перспективах валютно-экономической интеграции государств-членов ЕАЭС положены ими в основу рекомендаций по углублению экономической интеграции, созданию общего финансового рынка ЕАЭС. Приведенные в статье выводы и рекомендации по принятию мер для дальнейшего углубления экономической интеграции с государствами Евразийского экономического союза (ЕАЭС) актуальны для органов государственной власти Российской Федерации, в том числе экономических властей и органов дипломатии.

Ключевые слова: Европейский союз; Евразийский экономический союз; экономический валютный союз; экономическая интеграция; правовой статус; европейский опыт; выход из ЭВС.
\end{abstract}

\footnotetext{
Для цитирования: Бракки Д., Масленников В.В., Линников А.С. Кризисный сценарий для «Еврозоны»: варианты развития событий и уроки для экономических интеграционных объединений с участием России // Финансы: теория и практика. 2017. Т. 21. Вып. 5. С. 72 -81. УДК 339.9

JEL F36

DOI 10.26794/2587-5671-2017-21-5-72-81
} 


\section{THE TEXT}

\section{THE REVIEW OF EUROPEAN MONETARY INTEGRATION DEVELOPMENT}

The history of modern European monetary integration roots back to 1926 . It was then that in the course of Pan European Congress in Vienna the representatives of several nongovernmental organizations and some European states lobbying the creation of the United European States for the first time started to discuss possible creation of "European Customs Union" and introduction of a single "European currency". Preliminary action plan to accelerate integration was drawn up. [1]

However, in view of several economic and political reasons the real implementation of monetary integration started only in 1968 when the development of the project to shape the economic and monetary union (EMU) [2] in the context of European communities was launched. The creation of EMU occurred amid the confrontation of two European blocs: "economists" and "monetarists". "Economists", which included FRG, suggested putting off the adoption of a single European currency and keeping national currencies with floating rates at the first stage of the integration. But "Monetarists" led by France advocated the comprehensive monetary association with fixed rates of European currencies against common European currency unit.

In 1969, pursuant to the meeting of member state leaders the Council of EU took a decision to create both economic and monetary union at the same time. To draw up the Unions development plan the panel of experts led by Pierre Werner, the prime minister of Luxembourg, was formed. The plan worked out by the panel of experts (known as “Werner's plan”) was stipulated in a separate Resolution of European Communities Council dated 1971 which adopted the programme of economic and monetary union development at three stages by $1980^{1}$ However, it is worth mentioning that the document expressed the political will of several European states rather than be a guideline for action.

In 1971 the emerging EMU faced the first serious challenge when global monetary crisis initiated by the decision of the USA to give up gold standard for the American dollar struck. The European currencies fluctuation range expanded up to $2.25 \%$ put European reformers at a stand. However, the solution to the problem was found soon - in 1972 known as "currency snake" to reduce the fluctuation of European currencies against each other was introduced. And they adopted the range of $2.25 \%$ within which the fluctuation against the US

\footnotetext{
${ }^{1}$ JO. C28 du 27.03.1971. P. 1.
}

dollar was acceptable. If the currency rate was out of the range the national central banks were to conduct immediate currency interventions to stabilize the rate.

Nevertheless, even upon creation of European Monetary Cooperation Fund (EMCF) ${ }^{2}$ to provide lending to EMU member states it became evident that "currency snake" could be an efficient tool only for the states with relatively stable economies. For the others, the interventions which were unable to stabilize the rate turned out to be just the waste of funds. This is precisely why the number of "snake" proponents gradually went down. In 1979 the mechanism was abolished. The ideas stipulated in Werner's plan were to be implemented only partially due to unstable economic environment in Europe.

The next stage of European monetary integration was the creation of European Monetary System (EMS) in 1979. It owes its creation to Helmut Schmidt, the chancellor of FRG, and Valery Giscard d'Estaing, the president of the French Republic. It is worth mentioning that unlike Werner's Plan EMS is not only declared politically but stipulated in the law - by Regulation (EEC) № 3181/78 by the Council dated 18 December, 1978 on European Monetary System ${ }^{3}$. It is worth looking into the major features of EMS.

Firstly, the member states again started to define and shape their monetary policies.

Secondly, the American dollar ceased to be the benchmark and the states didn't take it into account while determining their currency rates any more.

Thirdly, "currency snake" mechanism was replaced by more flawless (from the standpoint of its creators) ECU, the "basket" of all member state currencies.

Therefore, the creation of ECS can be regarded as the first complete stage of European monetary integration development, as the previous stages turned out to be only trial and preparatory ones.

The second stage of monetary integration development in the EU started in the late 80s of XX century. The major tools of European Monetary System were already in place by that time. The idea to create a single bank for European states and a single currency resistant to fluctuations of other global currencies was already in the air. The European Commission put forward and idea to set up more flawless Economic and Monetary Union. Jacques Delors, the president of the European Commission, was appointed as the head of the committee which was to work out the plan of EMU creation and functioning.

\footnotetext{
${ }^{2}$ Regulation (EEC) № 90/73 of the Council dated 3 April 1973 on the establishment of Monetary Cooperation Fund // JO L 89 du 5.4.1973. P. 1.

${ }^{3}$ JO L 379 du 30.12.1978. P. 1.

${ }^{4}$ ECU-European currency unit.
} 
The document drawn up by the committee and named “Delors' Plan” came out in April 1989. In December 1989 the plan was approved at the meeting of the Council of Europe. The provisions of Delors' Plan were embodied in Maastricht Treaty on European Union of 1992. Therefore, the development of the modern EMU can be divided into three following stages.

The first stage (from 1990 till 1993) consisted of preparatory measures to facilitate entry of Maastricht Treaty into effect. In particular, the stage included elimination of obstacles to free movement of capital within the EU, financial rehabilitation of some member states, initial convergence in inflation rates and economic indicators.

The second stage (from 1994 till 1998) included the complete coordination of EU member states economies based on 4 criteria (known as economic convergence criteria): (1) convergence in inflation, (2) convergence in long term interest rates on the banking market, (3) remedying excessive budget deficit, (4) retaining sustainable currency rates till the adoption of the euro.

The final third stage started in 1999 and lasted till 2002. The major outcome of this stage was the complete adoption of the single European currency - the euro by EU member states. The corresponding banking and legal mechanisms were launched. At the start the euro was introduced for non-cash payments only, then to gradually replace national currencies in cash turnover cash money was printed.

That is precisely how European Economic and Monetary Union was created, which is still functioning with very few amendments to its legal framework. However, current economic and political landscape makes it impossible for the EU as a whole and its economy in particular to facilitate stable functioning. That is exactly why it is worth elaborating on the prospects of further EU and EMU development not only in glowing colours but analyzes the scenarios and mechanisms of Economic and Monetary Union breakup.

\section{THE MECHANISM OF EUROPEAN UNION MEMBER STATES EXIT FROM THE ECONOMIC AND MONETARY UNION}

Over more than nine years already - from the very beginning of global financial and economic crisis of 2008 - in Italy and admittedly in whole Europe there has been continuous elaboration on possible ways to conduct exit from the Eurozone. The discussion of this issue among academic economists and subsequently in legal circles and at the political level turned into the most active phase in 2011 and 2012 when a most severe financial and budget crisis hit Greece. Known as Brexit in 2016 and subsequent tough fight between Emmanuel Macron and Marine Le Pen in the course of the presidential election in France in April and May 2017 fueled another wave of discussion about the fate of EMU and the Eurozone. We shouldn't forget that Great Britain was among the Economic and Monetary Union members with derogation, i.e. fully exercising all four economic freedoms ${ }^{5}$, without being a part of the Eurozone. At the same time, Greece and France are full-fledged members of EMU and due to political and/or economic reasons their exit from the Eurozone might well bring about knock-on effect of wide-scale abolishment of the single currency by European states.

Regardless of worrying signs, which come out from time to time, European political and economic establishment avoids serious talk on possible exit of EU member states from the EMU reckoning that under the current legal framework the Eurozone breakup is impossible and/ or unfeasible. For instance, Mario Draghi, the president of the European Central Bank (ECB), claimed over and over again that the single European currency couldn't be merely abolished. [3] Even those who don't rule out the possibility of complete or partial breakup of the EMU (which has already been labelled by some scholars as "EURO-crack") are actively elaborating on considerable expenses and economic losses for those states which would take a decision on exit from the EMU and switching back to their national currencies. Especially significant losses are predicted for those states which will venture upon a unilateral exit from the EMU. However, forecasts of such expenses and losses are not voiced. Anyway, many distinguished politicians and prominent economists openly claim that bilateral abolishment of the euro by a single EU member state won't go in line with European economic integration development strategy and is a step backward in the European progress as a whole. However, the concerns that unilateral abolishment of the euro will hit mostly the pockets of the least wealthy population and middle class and reduce people's real income are far from being groundless. We already witnessed this phenomenon in a number of European states within the period of 1999-2002 when the euro was adopted.

That's where we cease to elaborate on possible implications of "EURO-crack" and are going to look into possible mechanisms for EU member states to leave the Economic and Monetary Union. We are of the opinion that the following options are possible: (1) EU member state exit from the Union (Brexit scenario) and (2) exit of one or more states from the Eurozone retaining the membership in the European Union. It should be specified that exit from the Eurozone (i.e. abolishment

\footnotetext{
5 "Four freedoms" is the term which appeared on the basis of free movement of goods, services, people and capital stipulated in treaty of Rome of 1957 OJ C325, 24.12.2002, p. 33-184.
} 
of the single currency) cannot be considered equal to the complete exit of a state from the EMU. As a matter of fact, leaving the "euro zone" a state gains the status of an EU member state with derogation ${ }^{6}$. Thus, let's look into possible scenarios of Eurozone breakup from the perspective of permissibility and feasibility under the current legal regulation of the EMU creation and functioning.

\subsection{Exit of a state from the European Union}

The possibility to leave the European Union and as a result the EMU has quite particular legal grounds. Brexit can be regarded as a vivid example. The exit of Great Britain from the EU is carried out under Article 50 of the Treaty on European Union (known as Article 50 of Lisbon Treaty $)^{7}$. It should be noted that already well known fiftieth article came into force relatively recently-01.12.2009. The article embodies the provisions which stipulate the procedure to denounce Lisbon Treaty and member state exit from the Union. The exit is effected under the constitutional law of the corresponding state by filing with the Council of Europe the notice proposing negotiations to solve the following tasks:

- to determine the terms of the agreement on member state exit from the Union;

- to determine the legal terms for further cooperation between the EU and the state leaving.

The Treaty on EU also specifies the rules of negotiations procedure to sing the agreement on the exit (paragraph 3, article 218 of the Treaty on the functioning of the European Union). The agreement on the exit is signed by the EU Council on behalf of the Union. The approval of the draft agreement is effected by qualified majority voting upon the approval of the European Parliament. The provisions of the Treaty on the EU cease to apply to the leaving state on the date when the agreement on the exit comes into force or, in the event such an agreement is not signed, in two years after the notice of the exit, unless the Council of Europe unanimously decides to prolong this term subject to the consent of the state concerned.

It is not surprising that Article 50 of Lisbon Treaty removes the representatives of the leaving member state in the Council of Europe and the EU Council from discussion and decision making process by the Council of Europe and the EU Council concerning the approval of the agreement on the exit and determination of the

\footnotetext{
${ }^{6}$ As of today these countries are Bulgaria, Great Britain, Hungary, Denmark, Poland, Romania, Croatia, Czech Republic, Sweden.

${ }^{7}$ Treaty on European Union // OJ C326, 26.10.2012, p. 44.
}

legal terms for further cooperation between the EU and the leaving state.

If a member state which left the Union files an application for a repeat accession then such an application is subject to the common procedure of new member acceptance without any exempts or preferences.

Technically, when a state leaves the EU its membership in the EMU is terminated automatically along with its representation in the institutions and bodies of the Union. In the near future we will be able to witness how the process of the member state exit from the EU will be effected in practice in the case of Great Britain. For right now we can only speculate on the terms of the agreement on the exit and nature of cooperation between the United Kingdom and the EU. However, we may suppose that in terms of the state economic security and wellbeing of Great Britain citizens Brexit may be not that painful since as a EMU member state with a derogation Great Britain was not a part of the Eurozone retaining its own national currency. The British are also optimistic in view of the low dependence, as opposed to other EU member states, of the British economy on the European market.

\subsection{Exit of a state from the European Union with further immediate application for repeat accession without taking part in the monetary union}

As we have already stated the Treaty on European Union implies the possibility and stipulates the procedure to leave the EU. On the other hand, the Treaty doesn't embody the provisions which specify the mechanism to leave the monetary union. The lack of such a mechanism brings about theoretical speculation, search for unconventional solutions and frankly speaking, even sheer fantasies. For instance, some Italian experts are serious when they examine the exit from the Union itself with immediate repeat accession as a solution to the issue of exit from the Eurozone. However, these very experts specify that this sort of solution to the problem is likely to cause aggressive political opposition from institutions and bodies of the EU and obviously, member states of the Union. [3]

\subsection{Exit of a state from the Eurozone while retain- ing the EU membership}

One would think that based on common sense with the possibility to leave the European Union in place there should be the possibility to leave the Eurozone through refusal to be a part of the monetary union. However, until recently the idea that the exit from the monetary union retaining the EU membership was not an option prevailed in the European establishment. This opinion was based on limited interpretation of the Treaty on EU. Especially, Jacques Attali, one of the Maastricht Treaty 
ideologists, repeatedly claimed that the fulfillment by the Eurozone states of economic convergence criteria stipulated in the Treaty on the EU led to such a level of national economies interdependence that their efficient functioning without being a part of the EMU is simply impossible. It must be said that such claims should be regarded as purely political declarations rather than economically or legally proved ideas ${ }^{8}$. In fact, the Treaty on European Union doesn't only contain the direct restriction but any direct and/or indirect limitation of member states right to leave the Eurozone and switch back to sovereign national currencies. Extended interpretation of the EU law provisions enables to work out a number of possible though quite complicated legal solutions to the issue of exit from the Eurozone. It should be noted that complexity and plurality of solutions is caused by nonhomogeneous legal framework of the EMU. Unlike the EU which legal framework is sophisticated to some extent but it is a single codified edition of Treaties on the European Communities, the European Economic and Monetary Union rests upon not a single treaty but a complicated and diverse set of rules and norms: provisions of the Treaty on EU and other treaties, agreements, protocols of decisions made by institutions and bodies of the EU let alone other numerous documents. We are going to provide a successive review of those solutions which are dictated by applicable rule of law in the EU.

\subsubsection{Termination of the Treaty on the grounds stipu- lated in Vienna Convention on the Law of Treaties (hereafter - Vienna Convention) ${ }^{9}$}

Article 62 of Vienna Convention empowers parties to treaties (which are the EU member states) refer to fundamental change of circumstances as the grounds for treaty termination or to leave it. Basically, article 62 represents rebus sic stantibus clause, i.e. the clause about changed circumstances, with respect to treaties. As of today, after a quarter of the century when the European Union was created and 18 years when the EMU was completely shaped, it is evident that many goals set for the Union by its ideologists and creators haven't been achieved. We imply the following, for instance:

- The Union shall offer its citizens an area of freedom, security and justice without internal frontiers, in which the free movement of persons is ensured in conjunction with appropriate measures with respect to external

\footnotetext{
${ }^{8}$ http://tass.ru/mezhdunarodnaya-panorama/4230697 - Le Pen and Macron had absolutely different opinions regarding Euro zone // TASS, 04.05.2017.

${ }^{9}$ The Convention of the Organization of the United Nations on the Law of Treaties (Vienna Convention) dated 23 May 1969, http://www.un.org/ru/documents/decl_conv/conventions/ law_treaties.shtml.
}

border controls, asylum, immigration and the prevention and combating of crime (p. 2 art. 3 of the Treaty on EU). Current migration crisis vividly demonstrates that the European Union is incapable of offering its citizens an area of freedom taken in conjunction with measures to take control over migration;

- The Union shall establish an internal market. It shall work for the sustainable development of Europe based on balanced economic growth and price stability, a highly competitive social market economy, aiming at full employment and social progress, and a high level of protection and improvement of the quality of the environment. It shall promote scientific and technological advance. It shall promote economic, social and territorial cohesion, and solidarity among Member States (p. 3 art. 3 of the Treaty on the EU). These provisions raise the biggest number of questions among European and particularly Italian "euro conservatives". From their perspective, high unemployment rate (particularly among youth), humiliatingly low wages (particularly in correlation to the cost of living) and continuous surge in social tension and aggression level in the society indicate inconsistent and inefficient Union policy and as a minimum its partial failure to achieve the goals and tasks set in the Treaty on EU. [3]

There are reasons to believe that incapability of the Union to fulfill its commitments set in the Treaty on EU over a long period of time can be regarded as a fundamental change of circumstances and the Treaty can be subject to termination under art. 62 of Vienna Convention;

Under art. 44 of Vienna Convention (Separability of Treaty provisions), "a right of a party to denounce, withdraw from or suspend the operation of the treaty may be exercised only with respect to the whole treaty unless the treaty otherwise provides or the parties otherwise agree", other than in respect of treaty obligations nonfulfillment cases (art. 60 of Vienna Convention). There is an opinion that incapability of institutions and bodies of the European Union and equally member states themselves to ensure complete implementation of social and economic guarantees set in the Treaty on EU represents nonfulfillment of treaty obligations;

Under art. 44 of Vienna Convention if the ground to terminate separate treaty provisions arises it can be referred to particularly if "the said clauses are separable from the remainder of the treaty with regard to their application". The separate provision of the Treaty on EU, article 4, stipulates that the Union shall establish the Economic and Monetary Union whose currency is the euro. Even the basic lexical interpretation of the Treaty on EU leads to the conclusion on separability of provi- 
sion of article 4 from the remainder of the treaty with regard to their application.

Based on the foregoing we conclude that current system of international law contains an efficient mechanism to denounce the Treaty on EU and/or its separate provisions. Meanwhile, we should remember that this mechanism is beyond the scope of the European Union law system. Based on the principle of international law supremacy over national one and supremacy of universal rules over the private ones we conclude that the rightfulness of full or partial denunciation of the Treaty on $E U$ on the part of the European Union member state on the grounds stated in the UN Convention on the Law of Treaties cannot be questioned by other member states along with institutions and bodies of the Union.

\subsubsection{Exit from the Eurozone on the grounds arising out of the Treaty on the functioning of the European Union $^{10}$.}

The Treaty on the functioning of the European Union (art. art. 139 and 140 of part 3 of the Treaty, title VIII "Economic and Monetary Policy", chapter 5 "Transitional Provisions") stipulates two legal statuses for the EU member states:

1) Monetary Union member states - participants of known as "Euro zone;

2) Member states with a derogation without being a part of the monetary union. The latter ones can be divided into three categories:

- the states which have fulfilled economic convergence criteria stated in the Treaty on EU but decided to exercise their right to refrain from taking part in the monetary union on "opt-out" principle (for instance, Great Britain and Denmark);

- the states which refrained from fulfilling one of the economic convergence criteria in advance (for instance, Sweden which was not a part of the European Monetary System within two years prior to the development of the EMU);

- the states which don't comply with economic convergence criteria by the decision of the EU Council (as at 1999 there are none).

The fact that the Treaty on the functioning of the EU embodies detailed provisions which determine legal status of member states with different levels of involvement in the EMU leads us to the conclusion that the shift from one status to another is quite possible. However, it is the lack of legally specified mechanism and clear procedure of transition from "full-fledged" membership in the EMU to the membership "with a derogation" which puzzles the proponents of the possibility to leave

\footnotetext{
${ }^{10} \mathrm{http}: / /$ eulaw.ru/treaties/tfeu.
}

the "Euro zone". At the same time, from the perspective of EMU apologists, the lack of such mechanisms and procedures is not a flaw through an oversight but a far-reaching intent of EMU founding treaties authors whose main goal was to rule out complete or partial breakup of the EMU.

Article 347, part 7 of the Treaty ("General and Final Provisions") stipulates that member states shall consult each other "with a view to taking together the steps needed to prevent the functioning of the internal market being affected by measures which a Member State may be called upon to take in the event of serious internal disturbances affecting the maintenance of law and order, in the event of war, serious international tension constituting a threat of war, or in order to carry out obligations it has accepted for the purpose of maintaining peace and international security". We reckon that this provision of the Treaty on the functioning of the EU can be interpreted as a mechanism for decision making including that of an economic nature in the event of crisis developments in national economies and socio-political spheres of individual member states. The developments in Greece in 2015 can be viewed as an example of serious internal disturbances constituting a threat to the functioning of the internal market.

The proponents of the EMU cohesion apparently dissemble when they claim that the procedure of exit doesn't exist at all and/or working out such a procedure at short notice is impossible. It is proved by the provisions of $\mathrm{p} .6$ art. 28 of the Treaty on the EU ("Simplified revision procedures") under which "the Government of any Member State, the European Parliament or the Commission may submit to the European Council proposals for revising all or part of the provisions of Part Three of the Treaty on the Functioning of the European Union relating to the internal policies and action of the Union. The European Council may adopt a decision amending all or part of the provisions of Part Three of the Treaty on the Functioning of the European Union. The European Council shall act by unanimity after consulting the European Parliament and the Commission, and the European Central Bank in the case of institutional changes in the monetary area. That decision shall not enter into force until it is approved by the Member States in accordance with their respective constitutional requirements". In other words, it implies that Title VIII of the Treaty on the functioning of the EU "Economic and Monetary Policy" may be amended and/ or supplemented, i.e. by the provisions which specify how a member states leaves the EMU and/or a state may change its status and become a member state "with a derogation". Therefore, the procedure of decision making on amending the provisions of the Treaty of the EMU is complicated and takes long but, nevertheless, exists 
and can be carried out given the political will of member states and the institutions of the EU.

\subsubsection{Criticism of the initiative on unilateral exit of a} member state from EMU drawing on the case of Italy Contrary to all sorts of claims and speculation made by some political circles, " 5 stars" movement for instance, unilateral exit of Italy from the Economic and Monetary Union through adoption of a national law, a decreelaw or even based on the results of a corresponding referendum cannot be carried out without complete denunciation of the Treaty on European Union and founding Treaties and Agreements of European Communities. The point is that art. art. 11 and 117 of the Italian Constitution restrain the sovereignty of the Republic and under them the legislative branch is subject to the provisions of the European Union law and international obligations undertaken by Italy (norms and rules of treaties). Moreover, under art. 75 of the Italian Constitution national referendum on the adoption or ratification of treaties is directly prohibited. Therefore, from the perspective of the Italian constitutional law exit from the EMU cannot be carried out without numerous complicated amendments to the Constitution of the Republic. However, membership in the Economic and Monetary Union keeps putting considerable strain on the Italian economy which cannot but fuel political tension inside the country and it creates relevant grounds for continuous heated debates over the possibility and necessity to leave the "Eurozone".

\section{EUROPEAN EXPERIENCE AND PROSPECTS OF ECONOMIC AND MONETARY INTEGRATION WITHIN EURASIAN ECONOMIC UNION}

Eurasian Economic Union is an international organization of regional economic integration possessing international legal personality and founded by the Treaty on the Eurasian Economic Union signed by the leaders of Belarus, Kazakhstan and Russian in Astana on 29 May $2014^{11}$. The signed Treaty certainly creates new prospects for common integration policy effected by EAEU member states. Thus, article 64 of the Treaty on the EAEU enunciate the following objectives and principles of agreed monetary policy of member states: ${ }^{12}$

1) phased harmonization and convergence of approaches to the formation and implementation of their monetary policy to the extent corresponding to the

\footnotetext{
${ }^{11} \mathrm{http}$ //www.eurasiancommission.org/ru/Pages/eec_quest. aspx - The definition on the official website of the Eurasian Economic Commission.

${ }^{12}$ The Treaty on the Eurasian Economic Union (signed in Astana 29.05.2014).
}

current macroeconomic integration and cooperation requirements;

2) establishment of the required organizational and legal conditions at the national and interstate levels for the development of integration processes in the monetary sphere, as well as for the coordination and harmonization of monetary policy;

3) inapplicability of any actions in the monetary sphere that may adversely affect the development of integration processes and, when such actions are inevitable, ensuring minimization of their consequences;

4) implementation of economic policy aimed at increasing confidence in national currencies of member states both on each state domestic currency market and international monetary markets:

Moreover, article 63 of the Treaty on the EAEU specifies particular economic indicators which are to be followed by member states:

- annual deficit of public sector consolidated budget shall not exceed 3 per cent of gross domestic product;

- public sector debt shall not exceed 50 per cent of gross domestic product;

- inflation rate (consumer price index) per annum (December to December of the previous year, in percentage terms) shall not exceed the lowest inflation rate among member states by more than 5 percentage points.

Along with that, the EAEU member states agreed on and signed known as Protocol 15 to the Treaty on the EAEU which provides a more detailed specification of integration processes regulation within the framework of the community. The basic analysis of these documents demonstrates that the authors were mostly guided by the EU experience. Thus, for instance, section 1 article 3 of Protocol 15 stipulates "coordination of national currencies exchange rate policy to ensure extended usage of member states national currencies for mutual settlements among member states residents, including arrangement of mutual consultations to develop and coordinate measures of monetary policy." Section 2 art. 3 of the Protocol stipulates "to ensure convertibility of their national currencies for the current and capital balance of payment items, without restrictions, by enabling unrestricted purchase and sale of foreign currency by residents of the Member States through the banks of the Member States." The indicators used as a basis for article 63 of the Treaty on the EAEU in many respects are similar to those of the EU founding documents provisions.

Apart from that, above mentioned clauses of Protocol 15 really remind of the first stage in the EU Economic and Monetary Union development. We reiterate that 
from 1990 till 1993 the EU carried out activities to ensure financial rehabilitation of member states and coordinated measures in the area of free capital movement within the EU.

However, unlike the European Union the EAEU member states are taking more moderate steps and therefore, we may assume that monetary integration process is going to take longer that in the EU. It is worth mentioning that slower integration processes are not so much explained by the will of member states but caused by unstable foreign political and economic landscape. Thus, the document "On major objectives of macroeconomic policy of the Eurasian Economic Union member states for 2017-2018" ${ }^{13}$ refers to the following adverse factors for the EAEU:

- fall in prices for major exports and deterioration in global economy and economic environment for core trading partners;

- extension of restrictive measures (sanctions) against Russia on the part of several states and international organizations with respect to access to external finances, products and technologies as well as implementation of joint projects;

- contraction or slowdown of the economy common more or less to the major global economies including the United States of America, the European Union states, the People's Republic of China, countries of Latin America.

All in all, the document states that current indicators of the EAEU member states don't correspond to those set in article 63 of the Treaty on the EAEU. As such, all the member states still exceed at least one of the indicators which define the economic development sustainability. Regardless of the fact that noncompliance with the es timated inflation rate (December to December of the previous year) by The Republic of Belarus, the Republic of Kazakhstan and the Russian Federation was less considerable compared with 2016 and amounted to 6.7, 4.6 and 1.5 percentage points respectively current readings are still not in line with the agreed rate.

It is worth mentioning that one of the major conditions for the adoption of a single currency within the EAEU is the need of businesses. Back in 2012 it was touched upon by Tatyana Valovaya, the Minister for the main areas of integration and macroeconomics of the EEC: "A single currency is the tip of monetary integration process. The adoption of a single currency should be driven by domestic economic needs of the

\footnotetext{
${ }^{13}$ https://docs.eaeunion.org/pd/ru-ru/0101539/pd_03032017 "On major objectives of macroeconomic policy of the Eurasian Economic Union member states for 2017-2018" on the official website of the EAEU.
}

Customs Union member states. This need should emerge in the course of economic integration. The European Union adopted the euro due to the pressing need of businesses in a single currency. Now we should thoroughly analyze and understand at which integration stage, at which particular period of time we are going to require a single unit of account in order to do away with business expenses." 14

So far, the major objective of the Eurasian Union is still the development of single financial market which should take place only by 2025 . To this end it is necessary to harmonize national financial systems and financial regulation so that any commercial bank established in the EAEU states can operate within the whole area of the Union without any extra registration or licenses. The supranational financial regulator, which is to be established in Kazakhstan, shall define level playing field for the whole Eurasian space ${ }^{15}$.

Within further almost 8 years the member states should implement the major principles of economic and monetary integration development. They include phasing, split-level and split-pace integration consistent with different economic development levels of member states, combination of market and state regulation, establishment of supranational regulating level [4].

The Eurasian Economic Union is comparatively a young international organization and the development of economic and monetary integration within it hasn't been appropriately specified in founding and other sorts of documents of the organization yet. Thereby, we have nothing to do but forecast what these economic and monetary integrations are to lead to in the end. Regardless of the fact that the European Union experience is actively used by both politicians and scholars in their research we shouldn't forget about the current global environment which has changed and is less stable and favourable than it used to be in Europe in 1990s of XX century. It is evident that the EAEU member states are to put much effort into harmonization of legislation and economic policy in compliance with the standards enshrined in the founding documents of the EAEU. Agreed macroeconomic policy is very essential for the EAEU states [5]. Since the first objective within the framework of economic integration is set for 2025 (the establishment of supranational financial regulator) we are only

\footnotetext{
${ }^{14} \mathrm{http}$ ///www.eurasiancommission.org/be/nae/news/Pages/ 20-06-2012.aspx - Tatyana Valovaya, Board Member (Minister) for the main areas of integration and macroeconomics of the EEC: "Eurasian Economic Union is going to become one of the fundamental elements of global economy" // 20.06.2012.

${ }^{15}$ https://interaffairs.ru/news/show/16744 - Tatyana Valovaya: The objective of the EAEU is to develop single financial market by 2025 // "International life" 18.01.2017.
} 
to find out what the ideas and plans provided in this article are going to result in.

In view of the foregoing it seems to be reasonable to recommend the public authorities of the Russian Federation (including economic policymakers and diplomatic agencies) to take the following measures in the course of further economic integration with the EAEU states:

1) To conduct thorough and comprehensive assessment of economic implications for Russia due to its participation in integration processes within the EAEU in the context of long term forecast of the Eurasian region economic development;

2) To carry out special-purpose research into the dynamics of integration and centrifugal processes with the EU in order to single out the factors which cause destabilization of international economic and monetary associations;

3) To elaborate on the mechanisms of complete and/ or partial denunciation of the Treaty on the EAEU provi- sions to serve the interests and to defend the economic sovereignty of the Russian Federation in such a situation when further participation in an integration association may lose its relevance and economic practicality;

4) To apply cross disciplinary economic and legal approach while planning and implementing economic foreign policy of Russia;

5) To stand up for the maximum possible independence of Russia from votes of other members of such organizations while coordinating mechanisms and procedures of decision making within the framework of economic cooperation international organizations with participation of the Russian Federation;

6) To rule out the possibility of constitutional and other technically legal obstacles to implementation of sovereign economic policy of Russia through denunciation of individual international obligations which may become excessively onerous in the context of foreign economic environment.

\section{REFERENCES}

1. Muet Y. Le débat européen dans l'Entre-deux-guerres. Paris: Économica, 1997. 158 p.

2. Olivi B. L’Europe difficile. Histoire politique de la Communauté européenne. Trad. de l'italien par Katarina Cavanna et Alessandro Giacone. Première édition française. Paris: Gallimard, 1998. 912 p.

3. Daniele Bracchi. Riflessioni giuridiche a proposito di euro e di Europa. Logos. Rivista politico-culturale. 25 Aprile 2017. URL: http://www.logos-rivista.it/index.php?option=com_content\&view=article\&id=1084\&Itemid=870.

4. Krasavina L.N. Conceptual Approaches to Reform Global Monetary System. Den'gi $i$ kredit $=$ Money and credit, 2010, no. 5, pp. 48-57.

5. Masalimova A. Systematic analysis of the Customs Union and single economic space resources management. Vestnik Finansovogo Universiteta = Bulletin of the Financial University, 2017, no. 2, pp. 158-178.

\section{ABOUT THE AUTHORS}

Daniele Bracchi - Lawyer of the Order of Advocates of the City of Milan (Italy), Researcher of European and global integration processes, Member of the research community Think-tank LOGOS (Milan)

danielebracchi@gmail.com

Vladimir Vladimirovich Maslennikov - Dr. Sci. (Econ.), Professor, Vice-rector of the Financial University for Scientific Work, Moscow, Russia

VVMaslennikov@fa.ru

Alexander Sergeevich Linnikov - Dr. Sci. (Econ.), Attorney-at-Law, Professor, Financial University, Moscow, Russia, Honorary Advocate of the Moscow Regional Chamber of Advocates, Moscow, Russia

las@leadcons.ru

\section{ИНФОРМАЦИЯ ОБ АВТОРАХ}

Даниэле Бракки - адвокат Ордена адвокатов города Милана (Италия), исследователь европейских и мировых интеграционных процессов, Член исследовательского сообщества Think-tank LOGOS, Милан, Италия danielebracchi@gmail.com

Владимир Владимирович Масленников - доктор экономических наук, профессор, проректор по научной работе, Финансовый университет, Москва, Россия

VVMaslennikov@fa.ru

Александр Сергеевич Линников - кандидат юридических наук, доцент, Финансовый университет, глава Коллегии адвокатов «Линников и Партнеры», Почетный адвокат Адвокатской Палаты Московской области, Москва, Россия

las@leadcons.ru 